UDC 141.319 .8

DOI: $10.26565 / 2226-0994-2018-59-3$

\title{
Nataliia Zahurska
}

\section{SPECULATIVE POSTHUMANISM: NATURALIZATION AND VITALIZATION}

The article considers speculative posthumanism as an actual approach in researching posthuman being condition. The article examines the influences of critical posthumanism and speculative realism on speculative posthumanism and at the same time, it argues the originality of speculative posthumanism, which consists in becoming divergential life-forms and their events. Trends, which significantly impacted on critical posthumanism and became its component parts of such as deconstruction, deleuzian conception and so on are considered in the article as a background for speculative posthumanism and are naturalizing and vitalizing. For example, rhizome is understood as a biological network of wide human descendants that are appropriate to human and nonhuman traits something like a human centipede. Thus principal excess of living in its immanence is stressed and the living is been considering as a specter or plenum, which resists to any metaphysical bounds. Instead of a metaphysical vitalism is used a strategic vitalism in the context of which multiplicity is been structuring fractally or aleatory, mixing human and non-human, digital or animal and so on, traits. Therefore, the article compares philosophical naturalism and vital realism, which in object-oriented ontology context deals with even non-living entities. Acceleration and singularity in such a case imply the dissipation of intensities in the death drive movement which is understanded as a (w)holeness and plexivity from templexity to teleoplexity. Thus, a living appears as a being-nothing, the form of form, the creation of creation. The article draws a contemporary conception of posthuman in the speculative posthumanism context as an ontogically uncertain one in principal. This article will be useful for developing a theoretical framework the realizing of posthuman being.

Keywords: speculative posthumanism, critical posthumanism, speculative realism, vital realism, human being, wide human descendants.

In the context of speculative realism (SP) of D. Roden the necessity of ontological novelty is especially emphasized, which complements NBIC (Nanotechnology, Biotechnology, Information Technology and Cognitive Science). Thus, the aim of the article is to consider not only psychological or even anthropological changes of posthuman being take place, but also the changes in a human being as such and his ontological position destabilizes incomprehensible and unknowable forms of life: «posthumans might be radically nonhuman and thus unintelligible in human terms» [Roden, 2010, p. 27].

D. Roden considers SP as a divergence, disjunction and at the same time convergence, conjunction of critical posthumanism (CP) and speculative realism (SR). As in CP, a wide range of postmodern concepts is considered; special attention is paid to their application to the posthumanist context and this is the main aspect of this research actuality. SP ontology unfolds in the space of assemblage ontology by G. Deleuze and in such a case post human possesses an aleatory flexibility, which conjugates human and non-human (animals, plants, machines, etc.) in a new configuration, which is disconnected with human in common sense. In the SP context the correlation between awareness of movement to singularity and nomadical singularity as a mainstream station of a human being is also traced. But whereas in CP posthuman is conceptualized byway of an adjective, in SP it is nominalized and acquires an independent meaning.

In a determinate sense, it is a kind of deconstruction of a human subjectivity. But, according to D. Roden, deconstruction of subjectivity fails a comprehension of a posthuman dispensation in the widest sense, i. e. the dispensation to wide human descendants (WHDs), which will realize textual multiplicities of virtual ontology and presence of an assemblage of biological and non-biological (in)dividuals. The tasks of article provide a study how WHDs

(C) Zahurska N. V., 2018. 
become subjects-effects, subjects-in-process, subjects-as-subjects and a pure alterity of becoming other. As for degree of development, in J. Derrida's concepts it means that deconstruction is not only anthropological, but also presupposes transcendental humanism. In the epistemological field of post-Kantian utopian and anti-realistic universal norms it has been deconstructed through speculations on operational systems with alternate functions and forms. On the other hand, it's stated that self-governing and self-transparent rational subject with a certain «nature» has exhausted itself. In this way, SP sorts with deep weird ecology in T. Morton's meaning from the point of view of the SR context.

Such an actual approach brings CP and SR with its object-oriented ontology, which from the position of SP appears as the independence of posthuman thinking from human cognitive forms. It may be marked as inhuman rationalism from the point of view of which there are a throng of inhuman things, including The Thing as Lacanian understanding of Freudian das Ding.

Transhumanism implies as an ethical claim of enhancement to a good thing. Thus, it can be thought of Human 1.0, 2.0, 3.0, etc. and it's expected that each descendant shall be better than previous. Such an improvement and augmentation implies that being posthuman is better than being human. But, as K. Hayles stresses, human and posthuman are in permanent interconfiguration and, in addition, posthuman is an umbrella concept, which combines a variety of its versions. Thus, posthuman always appears in an infinite set, the spectrum of versions, as Human n.0.

SP, by contrast, is a variety of metaphysical and ontic/ontological claims on the kinds of things that could exist in the world. It states that there could be posthumans. SP states that there could only be posthumans, that even would not be compared with humans. Posthuman becoming and experimentation with living being develop in multiple lines and it can also be fitted to the CP context. But in other relations, CP is recognized too theoretical and anthropocentrical. But if the posthuman is hardly understandable for the human and there is a human-posthuman disconnection and divergence with WHDs, CP may be useful through applying its philosophical and fictional writing on the posthuman.

From the SR context D. Roden in his turn adopts the critique of Kantian correlationism and anthropological exceptionalism and that enables to expand reality speculatively, including the reality of posthuman: «if we reject correlationism, however, we must hold that reality is not exhausted by any system of correlations» [Roden, 2010, p. 28]. But reality is enriched not only by natural processes and events, but also by the recourses to philosophy, literature, etc., i. e. all those areas of human experience that have been usually regarded as humanities. In this way, SP matches CP and SR in comparison to transhumanism, which suggests being of mind in nonhuman bodies.

But U. Thaker attracts attention to the foundational thought for unhuman limit, which means thought of life that transverses conceptualization of being and approves that there is «the possibility of a logic of life, though an inaccessible logic, one that is absolutely inaccessible to the human, the natural, the earthly - an "entelechy of the weird"» [Thaker, 2010, p. 23]. He appeals to Aristotelian understanding of contradictory logic as a background of thought itself and that is why, life cannot be thought. The life is weird itself and logic of contradictions may be descried as a logic of an inaccessible real. Comprehended in this way, life transverses limits of Kantian categories such as space, time, etc. and dimensions. Such an approach fits to the CP tendency of certain returning to a practical ancient subject from a modern cogitable subject or at least combines it.

According to U. Thaker, extra-dimensional biologies correspond to the extension of life ontologies and create the twofold framework of the principle-of-life and the bifurcation between Life and the living: «life is what subtracts itself from the living» [Thaker, 2010, p. 23]. But he accents the negation in comparison with Badiouian's subtraction, which is brought to nonorganic life or even living dead. Contradictive and being-nothing (néantisé by A. Badiou) life sorts with a superlative as nothing and rather life than living may be considered as the form of form, the creation of creation. 
Life is conceptualized as an excess of being including its own being, an excess up to a void as the immanent ground for the life of substance. It means immanence of nothing but itself, which sets of an univocity. In the concepts of J. Deleuze's immanence of nothing but itself there is a pure immanence as multiplicity, dynamic and processual plenum, which creates nothing else than immanence itself as irrelations of relations. Differance in such a case implies that although comprehensive differentiations are real, not all real differentiations are comprehended. Life in this sense may be sorted with the SR spectral life.

From these considerations U. Thaker proposes to designate uncontrolled, unbounded and disconnected posthumanism as Dark Posthumanism. Its darkness is due to the fact that appropriate experience does not lend itself to neither explicit nor implicit understanding. And in a determinate sense, Dark Posthumanism appears as Dark pantheism: «the limit to the thought of nature in the pantheist sense is the thought of extinction, the disaster, the limit-thought of life "after life". <...> Dark pantheism puts forth the challenge of thinking, under the sign of the negative, the conjunction of pure immanence and inventive life - with the caveat that this thought itself is thought as fundamentally exterior to all anthropomorphism» [Thaker, 2010, p. 229-230].

Teleology of Dark pantheism is rather teleoplexical, which is connected with templexity in N. Land's using. Such an approach correlates with CP problematic death of human. Particularly indicative in this sense are J. Derrida's considerations that an end and a telos of the human largely coincide. The human as a form dies precisely, when it is fully accomplished, and its telos is achieved and realized. The human ends in thought of being, which it is, accordingly thought of being ends too and the correlation between thought and being disseminates. Therefore, the human is not only its end itself, but also the end itself. Thus, proceeding from J. Derrida's consideration, there is a divergence, disjunction, disconnection and game between a telos and a death. That is why, death of the human always delays and precisely the rhythm of this delay and the interleaving of its step forms, lineament of posthumanity.

An acceleration, according to N. Land, is due not only to the drive to a singularity, but also to the death drive. «The death drive is not a desire for death, but rather ahydraulic tendency to the dissipation of intensities» [Land, 2012, p. 283]. That is why, posthuman makes himself as a body without organs, organism as fetishes making it with death. Posthuman metaphysic is a metaphysic of absence as a trace, which concludes and presents either: « $($ or $(0)(($ or $((())))))$ does not signify absence. It manufactures holes, hooks for the future, zones of unresolved plexivity, really so (not at all metaphorically)» [Land, 2012, p. 372]. Similarly, R. Negarestani describes openness as a schizo's strategies, schizotrategies and distinguishes in this relation so called $O$ holey complex, which conjugates the logic of the ground and the politics of whole. The wholeness in that case is proved by way of blank place as a place of a singularity, a virus. A virus is the embodiment of WHD, non-human agent, which simultaneously changes and secures integrity, wholeness. And an acceleration is caused by the need to adapt to the changes, due to virulence, WHD. "Whatever ultra modernity places under the dominion of signs, postmodernity subverts with virus. As culture migrates into partial-machines (lacking an autonomous reproductive system), semiotics subsides into virotechnics» [Land, 2012, p. 383]. Moreover, SP takes into account agential realism of $\mathrm{K}$. Barad, especially the conception of nonhuman agents in-between site. In this case, instinct unfolds to extinct. That is why, there is an acceleration up to a singularity, when a human being actualizes its vitalities.

But «speculative posthumanism is situated within the discourse of what many term "the singularity" in which at some point in the future some technological intervention will eventually produce a posthuman life form that diverges from present humanity. Whether this is advisable or not it will eventually happen. Yet, how it will take effect is open rather than something known» [Hickman]. If in V. Vinge's opinion, a singularity is a combination of a human and a machine in a single intelligent machine, then in D. Roden's opinion, there is not a definitive model of singularity, because of the significance of this transcendental event and its effects. Thus, in a determinate sense, a perceived singularity can be designated as a post-singularity, which 
partially resolves the transhumanist problematization of what will happen to the human being after the final improvement and whether the meaning of its becoming remains after this.

CP and SP converge in Vital Realism (VR) of posthuman life, which is closed to philosophical naturalism as a variety of functional truth-generating practices, rather than metaphysical claims or posthuman discourses. D. Roden attempts to vitalize and naturalize a deconstruction, as J.J. Botero has attempted to naturalize a phenomenology before. $\mathrm{He}$ considers it beyond transcendental and phenomenological frameworks and appealing to Freudian neurology of memory and then to cognitive processes in its entirety. «The deconstructive approach to meaning as simultaneously relational, open to recontextualisation (iteration), and recalcitrant to formalization is $\langle\ldots\rangle$ more pertinent to thinking about content in complex neural networks - and thereby, perhaps, the semiotics of our own biological networks» [Roden, 2006, p. 84]. Thus, CP is also understood as a kind of VR reckon in deconstructivist criticism of the metaphysics of presence. J. Derrida argues that «posthumousness is not part of the structure, $\langle\ldots\rangle$ every effort to build a synchrony in terms of paradigms, epistemes, contiguation, a totality in which we assume that the time is not out of joint. And time is out of joint, time is out of joint. That is, finally there is no contemporaneity, and the posthumous is already here. In that case, we would have to transform the problematic and take into account the fact that from the very beginning, posthumousness inhabits the work. Everything is homogeneously posthumous. That would be another way of recovering the synchrony of that. But it's only between many kinds of posthumousness that we have to draw lines, different lines» [Behler, 1996, p. 18-19]. Thus, J. Derrida emphasizes the fundamental variability of the posthuman, caused by his «not yet». This suspension causes the effect of derealization and spatial multiplication of properties, in the deconstructive context.

In Positions by J. Derrida the deceased human retains a very specific effectiveness of a particular process. Such an approach provides a transitions between the procedure of deconstruction and «a logic of excision into their accounts of generative systems such as texts and virtual multiplicities» [Roden, 2006, p. 32]. Effectiveness of a particular process is provided by cutting off transcendental signified, "original meaning" and excision of human minds, which may be compared with SR retreat from correlationism to contingency and autopsy of the human. An excision can also be understood as an excision of the posthuman from the human and is an impasse of pure speculation, whereas continuous realization of practical thinking is necessary. Thus, WHD appears as synthetic life-forms, including pure minds, for example, artificial minds on intangible media or in equally artificial bodies.

L. Alexandre's and J.-M. Besnier's transhumanistic research Do robots make love? can also be considered in the context of SP. Possible improvements in the human, its transformation into the posthuman one become the subject of speculation, moreover, the speculation of dialogical. This also fits the study in the context of CP, since dialogical speculations from the ancient times were characteristic precisely of the philosophical thought. The positions of the authors are polemical and even agoral: L. Alexandre fully supports improving innovations, J.-M. Besnier pays attention to their ethical aspects. He considers the opinion of the inventor of the holography of the Nobel laureate D. Gabor «everything that is technically achievable deserves to be realized, no matter what it costs ethically». Therefore, each section of the book is called in the question form, which then develops into a series of questions. The most interesting in this respect is the section May we make love with a robot?: «Even more troubling: machines could someday respond to what we have more intimate, sentiment and sexuality. Virtual reality seems to be indistinguishable from the real. But in the end, what do we want? A phantasm being embodied in a machine? Or what is projected phantasms in this machine?» [Alexandre and Besnier, 2016, p. 55].

Levi R. Bryant, aka Larval Subject, proposes to pay attention to the wildness and weirdness of WHD. That is why, Larval Subject resists any form of metaphysical vitalism and SR metaphysical realism. And his nick itself demonstrates, that the subjectivation of WHD is principally larval, virulent. Instead of metaphysical vitalism he suggests strategic vitalism, which is more in line with SP. The swirling, flickering multiplicity and variety is structured fractally. In the 
opinion of the deleuzian philosophizers, the fractal is the most adequate spatial metaphor for the post-oedipal, post-ontological world. From this point of view, the fractal is a metaphor, returning to the Real in all its multiplicity. It is his post-oedipality that avoids psychosis and attains Great Health with the inherent nomadic and virulent pleasure organization. Larval Subject also questions the possibility of a final interpretation in favor of experimentation, just as a fractal resists a glance.

Similarly, life also resists comprehension and vitality is a deep vitality by parity of reasoning of deep ecology as well. Strategic vitalism is conceptualized by analogy with G. Spivak's strategic essentialism, which implies approach to any entities as if it could be defined. It can also draw an analogy with describing openness as schizo's strategies, schizotrategies by R. Negarestani. If in the SR context any entity, including the human one, is treated as an object, in more close to the CP vital realism or strategic vitalism context, any entity, even non-living entities, is treated as animals: «nonhumans are agencies or animals. In this world-scheme, they are not brute and passive bits of matter, but rather are 'animals' in their own right» [larvalsubjects].

It allows considering object-oriented ontology as the fractured politic of thinking, which grants to any entity of animal rights, differencing from the human rights, it implies a spontaneous activity. Treating as an animal makes it possible, on the one hand, to avoid extreme anthropomorphism, and, on the other hand, redundant objectification. It is the animal that embodies the end in itself, its own teleology, more than human. Posthuman resists to a virus or an animal as an equal in the differences, which imply multiplicity of regimes of attraction, because of just animals are always surprising.

But vital realism of Levi R. Bryant intersects with CP in connection with the appeal to the properly philosophical conceptions. It «invites us to always be on the lookout for the Lucretian swerve, taking care not to reduce things to our concept of things. As such, it helps to render us sensitive to the aleatory and to, paradoxically, anticipate the aleatory insofar as things always harbor hidden depths and powers that we can never fully master» [larvalsubjects]. In addition to the appeal to epicureanism, in the context of which knowledge and pleasure do not come into conflict, it is obvious that the OOO trends are evolving and developing in connection with the appeal to the object in all its aleatory.

In conclusion it is worth noting, that sort of tendency of development of CP strengthens the degree of it naturalizing and vitalizing in addition to the NBIC, which is a valuable contribution to $\mathrm{CP}$ as a actual conception of the becoming of a human being in WHD.

\section{REFERENCES}

Alexandre, L., \& Besnier, J.-M. (2016). Les robots font-ils l'amour? Le transhumanisme en 12 questions. Paris: Dunod.

Behler, E. (1996). The Contemporary and the Posthumous. Roundtable Discussion. Surfaces, VI (102), 5-42. Retrieved from http://www.pum.umontreal.ca/revues/surfaces/vol6/behler.html.

Hickman, S. C. (2014). David Roden's Speculative Posthumanism and the Future of Humanity (Part 2). Retrieved from https://socialecologies.wordpress.com/2014/10/21/david-rodensspeculative-posthumanism-the-future-of-humanity-part- 2 .

Land, N. (2012). Fanged Noumena. Collected writings 1987-2007. UK: Urbanomic; Sequence Press.

Larvalsubjects. (2008). Strategic Vitalism and the Wilderness. Retrieved from https://larvalsubjects.wordpress.com/2011/09/21/strategic-vitalism-and-the-wilderness.

Roden, D. (2010). Deconstruction and Excision in Philosophical Posthumanism. Journal of Evolution and Technology, 21 (1), 27-36.

Roden, D. (2006). Naturalising Deconstruction. Continental Philosopby Review, 38 (1-2), 71-88. doi: https://doi.org/10.1007/s11007-005-9004-z.

Roden, D. (2015). Posthuman Life: Philosophy at the Edge of the Human. New-York, London: Routledge.

Thaker, E. (2010). After life. Chicago, London: University Of Chicago Press. 


\section{Zahurska Nataliia V.}

D.Sc. in Philosophy, Professor of the Department of Theoretical and Practical Philosophy named after Professor J. B. Schad

V. N. Karazin Kharkiv National University

6, Svobody sqr., 61022, Kharkiv, Ukraine

E-mail: zagurskaya@karazin.ua

ORCID: http://orcid.org/0000-0001-5142-8064

Article arrived: 03.10.2018

Accepted: 07.11.2018

\section{СПЕКУАЯТИВНИЙ ПОСТГУМАНІЗМ: НАТУРААІЗАЦІЯ ТА ВІТААІЗАЦІЯ}

\section{Загурська Наталія Віталіївна}

Аоктор філософських наук, професор кафедри теоретичної і практичної філософії імені професора Й. Б. ШаАа

Харківський національний університет імені В. Н. Каразіна

м. Свободи, 6, Харків, 61022

E-mail: zagurskaya@karazin.ua

ORCID: http://orcid.org/0000-0001-5142-8064

В статті розглядається спекулятивний постгуманізм як актуальний піАхіА у досліАженні умов АюАської істоти. В статті АосліАжується вплив критичного постгуманізму та спекулятивного реалізму на спекулятивний постгуманізм і водночас доводиться оригінальність спекулятивного постгуманізму, який полягає в становленні дивергентних життєформ та їхніх подій. Напрямки, що значно вплинули на критичний постгуманізм і стали його скАадовими частинами, як-от Аеконструкція, Аельозіанська концепція тощо, розглядаються в статті як засади спекулятивного постгуманізму, а також натуралізуються та віталізуються. НаприклаА, ризома розумісться як біологічна мережа загалу Аюдських нащадків, які апроприюють як АюАські, так і не-людські риси, (щось подіб̈не Ао «АюАської багатоніжки»). Такий принциповий надлишок проживання в його іманентності розглядається як спектр або повнота, яка протистоїть будь-яким метафізичним межам. Замість метафізичного віталізму застосовується стратегічний віталізм, у контексті якого багатоманіття структурується фрактально та алеаторно, змішуючи АюАські та нелюАські, Аигітальні та тваринні тощо риси. Так, в статті порівнюються філософський натуралізм та вітальний реалізм, який в контексті об’єкт-орієнтованої онтології має справу навіть з не-живими істотами. Акселерація та сингулярність у цьому разі мають на увазі диссипацію інтенсивностей в русі смертельного потягу, який розуміється як цілесність і плексивність віА темплексивності до телеоплексивності. Таким чином, проживання постас як буття-нічим, формою форм, творенням творення. У статті окреслюється сучасна концепція постлюдини в контексті спекулятивного постгуманізму як принципово онтологічно невизначена. Стаття може стати в нагоді А^я розвитку теоретичного Ааштування усвідомлення постАюАської істоти.

КАючові слова: спекулятивний постгуманізм, критичний постгуманізм, спекулятивний реалізм, вітальний реалізм, Аюдська істота, загал АюАських нащадків.

Стаття надійшла Ао редакції: 03.10.2018

Схвалено Ао Аруку: 07.11.2018

\section{СПЕКУАЯТИВНЫЙ ПОСТГУМАНИЗМ: НАТУРААИЗАЦИЯ И ВИТААИЗАЦИЯ}

\section{Загурская Наталья Витальевна}

Аоктор философских наук, профессор кафедры теоретической и практической философии имени профессора И. Б. ШаАа

Харьковський национальный университет имени В. Н. Каразина

пл. Свободы, 6, Харьков, 61022

E-mail: zagurskaya@karazin.ua

ORCID: http://orcid.org/0000-0001-5142-8064 
В статье рассматривается спекулятивный постгуманизм как актуальный подход в исследовании условий человеческого существа. В статье исследуется влияние критического постгуманизма и спекулятивного реализма на спекулятивный постгуманизм, и в то же время Аоказывается оригинальность спекулятивного постгуманизма, который состоит в становлении Аивергентных жизнеформ и их событий. Направления, которые значительно повлияли на критический постгуманизм и стали его составными частями, такие как Аеконструкция, Аельозианская концепция и т. А., рассматриваются в статье как основания Аля спекулятивного постгуманизма, а также натурализируются и витализируются. Например, ризома понимается как биологическая сеть общности человеческих потомков, которые аппроприируют как человеческие, так и не-человеческие черты (нечто подобное «человеческой многоножке»). Такой принципиальный избыток проживания рассматривается как спектр или полнота, которая противостоит каким-либо метафизическим границам. Вместо метафизического витализма используется стратегический витализм, в контексте которого многообразие структурируется фрактально и алеаторно, смешивая человеческие и нечеловеческие, Аигитальные и животные и пр. черты. Так, в статье сравниваются философский натурализм и витальный реализм, который имеет Аело даже с не-живыми существами. Акселерация и сингулярность в таком случае имеют ввиду Аиссипацию интенсивностей в Авижении смертельного влечения, которое понимается как целестность и плексивность от темплексивности до телеоплексивности. Таким образом, проживание оказывается бытием-ничем, формой форм, творением творения. В статье очерчивается современная концепция постчеловека в контексте спекулятивного постгуманизма как принципиально онтологически неопределенная. Статья может стать полезной Аля развития теоретического обустройства осознания постчеловеческого существа.

Кмючевые слова: спекулятивный постгуманизм, критический постгуманизм, спекулятивный реализм, витальний реализм, человеческое существо, размах человеческих потомков.

Статья поступила в редакцию: 03.10.2018

Утверждена к печати: 07.11.2018 